\title{
The effect of endotracheal aspiration on QT interval in intensive care unit patients
}

\section{Yoğun bakım üinitesinde yatan hastalarda endotrakeal aspirasyonun Qt intervali üzerine etkisi}

\author{
Onur Avcı ${ }^{1}$, Oğuz Gündoğdu ${ }^{1}$, Zuhal Gülsoy ${ }^{1}$, Sinan Gürsoy ${ }^{1}$, İclal Özdemir Kol ${ }^{1}$, Kenan Kaygusuz ${ }^{1}$, \\ Şerife Karagözoğlu², Fatma Tok Yildız²
}

1Cumhuriyet University Faculty of Medicine Department of Anesthesiology and Reanimation, Sivas/Turkey.

2Cumhuriyet University Faculty of Health Sciences Department of Nursing

Corresponding author: Onur Avc1, MD, Cumhuriyet University Faculty of Medicine Department of Anesthesiology and Reanimation, Sivas/Turkey.

E-mail: dronuravci@gmail.com

Received/Accepted: March 21, 2019/March 25, 2019

Conflict of interest: There is not a conflict of interest.

\section{SUMMARY}

Objective: The intensive care unit (ICU) environment and applied methods may lead to a significant stimulation of sympathoadrenal activity. There are studies about the direct connection between increased plasma catecholamine levels during sympathetic activation and QT interval. Therefore, the aim of this study is to determine the effects of endotracheal aspiration on QT interval and QT dispersion.

Method: 90 patients connected to a mechanical ventilator from the ages of 30-70 in ICU were taken into study. Patients taking any drug that prolongs QT, patients with unstable hemodynamia and congenital QT prolongation were excluded. Preoxygenation was done to all patients with $100 \% \mathrm{O}_{2}$ administration for 1 minute before the endotracheal aspiration (ET). Age, diagnosis, weight, systolic blood pressure (SBP), diastolic blood pressure (DBP), mean arterial pressure (MAP), heart rate $(\mathrm{HR})$, peripheral oxygen saturation $\left(\mathrm{SpO}_{2}\right)$, QT, QTc, Glasgow Coma Score (GCS) values were recorded before, during, 5 minutes after and 10 minutes after the ET aspiration.

Results: During ET aspiration, the mean QTc value was $445.1 \pm 23.0$ milliseconds (ms), the mean QT value was $379.2 \pm 19.3 \mathrm{~ms}$. In $14 \%$ of the patients included in the study, basal QTc values above $420 \mathrm{~ms}$ were found to be prolonged. According to basal values, QT and QTc intervals were prolonged in almost all patients during, 5 minutes after and 10 minutes after the ET aspiration.

Conclusions: QT interval prolongation should always be checked by calculating corrected QT interval, and ICU physicians need to be more careful in patients with coronary heart disease and congenital prolonged QT interval in terms of fatal ventricular arrhythmias.

Keywords: QT interval, QTc interval, endotracheal aspiration

ÖZET

Amaç: Yoğun bakım ortamı ve uygulanan yöntemler sempatoadarenal aktivitenin belirgin stimülasyonuna yol açabilir. Sempatik aktivasyon sırasında plazmada artan katekolamin düzeyleri ile QT intervali arasında direkt bağlantı olduğu yönünde yayınlar mevcuttur. Bu sebeple bu çalışmanın amac1; rutinde uygulanan endotrakeal aspirasyonun aritmi belirteçleri olan QT intervali ve QT dispersiyonu üzerine etkilerini ortaya koymaktır.

Yöntem: Solunum yetmezliği nedeniyle yoğun bakım ünitesine alınmış, mekanik ventilatöre bağlı ve yaşları 30-70 arası olan bireylerden toplam 90 hasta çalışmaya dahil edildi. Qt intervalini uzatan ilaç kullanan, hemodinamisi stabil olmayan hastalar ile edinsel ya da konjenital uzun QT sendromu olan hastalar çalışma kapsamına alınmadı. Tüm hastalara endotrakeal aspirasyondan (ET) 1 dakika öne $\% 100 \quad \mathrm{O}_{2}$ ile preoksijenizasyon uygulandı. Tüm hastaların yaşları, tanıları, sistolik kan basınçları (SAB), diyastolik kan basınçları (DAB), ortalama kan basınçları (OAB), kalp atış hızları $(\mathrm{KH})$, periferik oksijen saturasyonları $\left(\mathrm{SpO}_{2}\right)$, QT, QTc değerleri, Glasgow Koma Skoru puanları endotrakeal aspirasyondan 5 dakika önce, aspirasyon sırasında, aspirasyondan 5 ve 10 dakika sonra kaydedildi.

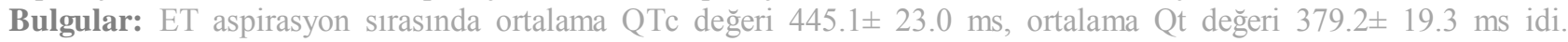
Çalışmaya alınan hastaların \% 14'ünde bazal QTc değerlerinin 420 ms'nin üzerinde olduğu tespit edildi. Bazal değerlere 
göre hemen hemen tüm hastalarda; ET aspirasyon sırasinda ve aspirasyondan 5 ile 10 dakika sonra QT ve QTc aralıkları uzamıștır.

Sonuç: QT intervali uzaması her zaman düzeltilmiş QT aralığı hesaplanarak kontrol edilmeli ve yoğun bakım ünitesi hekimlerinin koroner kalp hastalığı ve konjenital uzun QT sendromu olan hastalarda ölümcül ventriküler aritmiler açısından daha dikkatli olmaları gerekmektedir.

Anahtar sözcükler: Qt intervali, Otc intervali, endotrakeal aspirasyon

\section{INTRODUCTION}

Cardiac arrhythmias are frequently seen in intensive care unit patients and they are the complications that are responsible for mortality. Electrolyte imbalances, sympathetic nervous system activation, prolonged congenital or acquired QT syndrome, many drugs, such as general and local anesthetics can cause arrhythmias in intensive care patients 1,2 . Acquired QT prolongation may develop with heart or nervous system disorders, temperature disorders, electrolyte disorders, endocrine, and metabolic disorders and pharmacological agents used $^{3,4}$. It has been reported that long QT interval may be responsible for ventricular arrhythmias and sudden death without cause. The QT interval indicates the time of ventricular repolarization in the electrocardiogram (ECG). Prolongations in the QT interval can be used as a guide in determining ventricular repolarization abnormalities and in detecting the risk of arrhythmias ${ }^{5}$.

Application of mechanical ventilation, non-stop lighted environment, invasive and non-invasive methods can cause stress, anxiety, and agitation in intensive care patients. The intensive care environment and applied methods may lead to a significant stimulation of sympathoadrenal activity. Sympathetic stimulation may lead to hypertension, tachycardia, and arrhythmia. Tachycardia; While increasing myocardial oxygen consumption, it decreases diastolic filling, which prevents effective coronary flow. There are studies about the direct connection between increased plasma catecholamine levels during sympathetic activation and QT interval ${ }^{6}$.

Sedations, impaired mucociliary activity, the presence of endotracheal tube, chronic obstructive pulmonary disease (COPD) and infection causes the accumulation of secretions in the respiratory tract in patients connected to a mechanical ventilator ${ }^{7-10}$. However, patients cannot remove these secretions themselves ${ }^{8,11}$. Thus, secretions in the airways may accumulate and cause mechanical obstructions. For this reason, it is often necessary to aspirate secretions to provide airway clearance ${ }^{8,} 11,12$. In this context, the tracheal aspiration procedure applied to intensive care patients is a vital nursing intervention and endotracheal aspiration is applied routinely in patients with mechanical ventilation. Endotracheal aspiration is a painful and disturbing method for patients and may lead to stimulation of sympathoadrenal activity. Most intensive care patients are unstable cardiac patients. Arrhythmias seen in these patients continue to be an important problem. Therefore, the maintenance of hemodynamic monitoring, close monitoring, and maintenance of airway patency in patients with mechanical ventilator requires a multidisciplinary approach in cooperation with the physician and nurse.

The effects of many drugs used in intensive care units and other clinics on QT interval and also the effects of many applications in cardiac diseases on QT interval were investigated. However, the effect of the aspiration procedure, which is frequently applied routinely in critical patients connected to a mechanical ventilator, is not known on the arrhythmia potential. In this context, being aware of the risk factors related to endotracheal aspiration by team collaboration and to be able to perform proper and effective aspiration by taking necessary precautions are extremely important to prevent severe complications. Today, evidence-based practices have gained weight and the effects of all nursing interventions on organism have gained importance. Therefore, the aim of this study is to determine the effects of endotracheal aspiration on QT interval and QT dispersion, which are the markers of arrhythmia.

\section{MATERIAL AND METHODS}

After approval of the Ethics Committee and informed consent of the patients; This crosssectional study was designed to investigate the effect of endotracheal aspiration on QT interval and QT dispersion. The data of the study were continued to be collected in the intensive care unit until a total of 90 patients connected to a mechanical ventilator from the ages of 30-70 were admitted due to respiratory failure. Patients with anticholinergic, antiarrhythmic, vasopressor, vasodilator and hypotensive medication, patients with electrolyte imbalance, unstable hemodynamia and patients with acquired or congenital long QT syndrome were excluded from the study. In 
addition, patients who were not informed or not allowed by their relatives were excluded from the study. Patients who had a change in consciousness during the study, who had hemodynamic insufficiency and need for endotracheal tube replacement and those who needed anticholinergic, antiarrhythmic, vasopressor and vasodilator drugs were excluded from the study.

After the respiratory and cardiac monitoring of the patients who were admitted to the intensive care unit due to respiratory failure, 12 leads ECGs were taken, simultaneously systolic blood pressure (SBP), diastolic blood pressure (DBP), mean arterial pressure (MAP), heart rate (HR), and peripheral oxygen saturation $\left(\mathrm{SpO}_{2}\right)$ values were recorded. These values were taken as the basis. When endotracheal aspiration was needed, endotracheal aspiration was performed with preoxygenation $\left(100 \% \mathrm{O}_{2}\right.$ for 1 minute). During the aspiration procedure, 12 leads ECGs were taken again 5 and 10 minutes after the aspiration and simultaneous SKB, DBP, OCD, HR and $\mathrm{SpO}_{2}$ values were recorded. ECG recordings were performed at a height of $1 \mathrm{mV}$ and at a speed of $25 \mathrm{~mm} / \mathrm{sec}$. The longest QT distance from all leads in ECG recordings; was measured by 2 researchers who did not know the groups and the distance of the RR in the same lead was measured and the QTc (corrected QT) distance was calculated with the Bazzet formula $\left(\mathrm{QT}_{\mathrm{c}}=\mathrm{QT}\right.$ interval / $\sqrt{ } \mathrm{RR}$ interval). Calculated QT and QTc values were recorded. The state of consciousness
(GCS) was recorded at the time of recording the patient data. In addition, ECG (change in ST-T, arrhythmia, etc.) changes were recorded during routine procedures if it had changes.

The study was performed in the intensive care unit of the Department of Anesthesiology and Reanimation. Hemodynamic and respiratory data of the study were obtained from the Drager, XL model monitor. The device of "Mortara instrument ELI 250" brand was used in ECG shooting. The parameters used in the study and the aspiration process are routinely used for the patient group included in the study. At the end of the study, the values before and after the endotracheal aspiration (QT distance in ECG, blood pressure, heart rate) were compared. In the study, the correlation between the level of consciousness and QT interval was also examined.

\section{Statistical Method}

The data obtained from our study were loaded into the SPSS (ver: 22.0) program. When the parametric test assumptions were performed in the evaluation of the data, variance analysis, Tukey test, significance test of the difference between two peers were used. When the parametric test assumptions were not fulfilled, Kruskal-Wallis test, Man-Whitney U test, Wilcoxon test and ChiSquare test were used and the margin of error was taken as 0.05. Spearman test was used to investigate the correlations.

\section{RESULTS}

Of the participants, 50 were male and 40 were female. Other demographic data are shown in (Table 1).

Table 1: Distribution of demographic data

\begin{tabular}{|l|c|c|c|}
\hline & Minimum & Maximum & Mean \pm SD \\
\hline Age (year) & 28 & 73 & $59.66 \pm 12.53$ \\
\hline Weight (kg) & 40 & 120 & $76.02 \pm 14.63$ \\
\hline
\end{tabular}

When the diagnoses of the patients were grouped, $22(24.4 \%)$ patients were diagnosed with cardiac disease and $68(75.6 \%)$ patients had no cardiac pathology.
The distribution of QT and QTc values measured at basal (before aspiration), during aspiration, 5 min after aspiration and 10 min after aspiration is shown in (Table 2). 
Table 2: Distribution of QTc data

\begin{tabular}{|l|c|c|c|}
\hline & Minimum & Maximum & Mean \pm SD \\
\hline QT-basal & 294 & 384 & $345.2 \pm 19.6$ \\
\hline QT-aspiration & 340 & 426 & $379.2 \pm 19.3$ \\
\hline $\begin{array}{l}\text { QT-5 minutes after } \\
\text { aspiration }\end{array}$ & 301 & 402 & $360.3 \pm 20.2$ \\
\hline $\begin{array}{l}\text { QT-10 minutes after } \\
\text { aspiration }\end{array}$ & 296 & 385 & $348.8 \pm 20.3$ \\
\hline QTc-basal & 334 & 434 & $395.5 \pm 23.2$ \\
\hline QTc-aspiration & 358 & 496 & $445.1 \pm 23.0$ \\
\hline $\begin{array}{l}\text { QTc-5 minutes after } \\
\text { aspiration }\end{array}$ & 354 & 463 & $422.4 \pm 21.3$ \\
\hline $\begin{array}{l}\text { QTc-10 minutes after } \\
\text { aspiration }\end{array}$ & 336 & 445 & $402.6 \pm 23.4$ \\
\hline
\end{tabular}

$* \mathrm{p}<0.001$

**Values were given as "millisecond" (ms)

There were significant positive correlations between QT and QTc parameters measured at different times in the same individual and between each other in all measured times $(p<0.001)$. When the Spearman correlation coefficients of these correlations were analyzed, the largest was found to be 0.889 (between basal QT and QT measured 10 min.after aspiration) and the smallest was found to be 0.257 (between basal QTc and QTc measured during aspiration) (Table 3).

Table 3: QT-QTc correlations

\begin{tabular}{|c|c|c|c|c|c|c|c|c|c|}
\hline & & qtbasal & qtasp & qtasp5 & qtasp10 & qtcbasal & qtcasp & qtcasp5 & qtcasp10 \\
\hline \multirow[t]{2}{*}{ qtbasal } & s.c.c. & 1 & 0.678 & 0.744 & 0.889 & 0.809 & 0.391 & 0.569 & 0.732 \\
\hline & $\mathrm{p}$ & . & 0.000 & 0.000 & 0.000 & 0.000 & 0.000 & 0.000 & 0.000 \\
\hline \multirow[t]{2}{*}{ qtasp } & s.c.c. & & 1 & 0.834 & 0.749 & 0.58 & 0.592 & 0.693 & 0.661 \\
\hline & $\mathrm{p}$ & & & 0.000 & 0.000 & 0.000 & 0.000 & 0.000 & 0.000 \\
\hline \multirow[t]{2}{*}{ qtasp5 } & s.c.c. & & & 1 & 0.859 & 0.627 & 0.491 & 0.73 & 0.68 \\
\hline & $\mathrm{p}$ & & & ㅇ & 0.000 & 0.000 & 0.000 & 0,000 & 0.000 \\
\hline \multirow[t]{2}{*}{ qtasp10 } & s.c.c. & & & & 1 & 0.744 & 0.351 & 0.596 & 0.805 \\
\hline & $\mathrm{p}$ & & & & . & 0.000 & 0.000 & 0.000 & 0.000 \\
\hline \multirow[t]{2}{*}{ qtcbasal } & s.c.c. & & & & & 1 & 0.257 & 0.536 & 0.877 \\
\hline & $\mathrm{p}$ & & & & & . & 0.007 & 0.000 & 0.000 \\
\hline \multirow[t]{2}{*}{ qtcasp } & s.c.c. & & & & & & 1 & 0.751 & 0.319 \\
\hline & $\mathrm{p}$ & & & & & & . & 0.000 & 0.001 \\
\hline \multirow[t]{2}{*}{ qtcasp5 } & s.c.c. & & & & & & & 1 & 0.664 \\
\hline & $\mathrm{p}$ & & & & & & & . & 0.000 \\
\hline \multirow[t]{2}{*}{ qtcasp10 } & s.c.c. & & & & & & & & 1 \\
\hline & $\mathrm{p}$ & & & & & & & & \\
\hline
\end{tabular}

qtasp: QT during aspiration

qtasp5: QT; 5 minutes after aspiration,

qtasp10: QT; 10 minutes after aspiration

s.c.c.: Spearman correlation coefficient

When the QT and QTc values measured at different times in the same individuals were compared in pairs, all results were found to be significant ( $p<0.001)$. 
There was no significant correlation between mean arterial pressure, systolic blood pressure, diastolic blood pressure values and QT and QTc ( $>$ > 0.05).

The distribution of QT and QTc values in patients with cardiogenic diagnoses and in patients without a cardiogenic diagnosis was also found to be significant $(\mathrm{p}<0.05)$.

The distribution of $\mathrm{SpO} 2$ values was not significant ( $p>0.05)$. No significant correlation was found between $\mathrm{SpO}_{2}$ and QT and QTc (p> $0.05)$.

It was determined that 15 patients had arrhythmia during aspiration and 9 of them had cardiogenic diagnoses.

When the QT and QTc values of the patients with Glasgow Coma Score (GCS) $\leq 8$ and the patients with GCS $\geq 9$ were compared, the result was insignificant $(\mathrm{p}>0.05)$.

\section{DISCUSSION}

The QT interval involving the range from the beginning of the $\mathrm{Q}$ wave to the end of the $\mathrm{T}$ wave in electrocardiography (ECG) shows ventricular depolarization through repolarization. The QT interval is inversely proportional to the heart rate. QT interval is confirmed by the Bazett formula $(\mathrm{QTc}=\mathrm{QT}$ interval $/ \sqrt{ } \mathrm{RR}$ interval). QT interval is considered to be prolonged above the QTc value of $420 \mathrm{~ms}$ while it is considered to be normal when the QTc is below $420 \mathrm{~ms}^{13}$. QTc interval is longer in women than men ${ }^{14}$. An increase in the QTc interval of more than $500 \mathrm{~ms}$ or an increase of $60 \mathrm{~ms}$ or more from the basal value represents an increased risk of torsades de pointes (TdP) or an increased risk of developing a cardiac problem 15

In intensive care, prolonged QT is frequently encountered due to intensive drug therapies. Haloperidol, dexmedetomidine, and other sedative agents used to prevent agitation and delirium in the intensive care unit and antipsychotics such as risperidone, quetiapine, antihistamines, antiemetics, catecholamines, antidepressants, narcotics, some antibiotics (azithromycin, levofloxacin) cause QT prolongation ${ }^{16,17,18}$. In addition, electrolyte imbalances such as hypokalemia and hypomagnesemia increase the susceptibility to arrhythmias ${ }^{19}$. QT interval is prolonged in neurologic conditions such as subarachnoid hemorrhage, stroke, in cardiac pathologies such as, myocardial infarction, cor pulmonale, atrioventricular block, and in other conditions such as, prolonged fasting 19, 20, 21.
None of the patients included in our study were given an agent to prolong the QT interval.

In $14 \%$ of the patients included in the study, basal QTc values above $420 \mathrm{~ms}$ were found to be prolonged. While this rate was found to be $24 \%$ in Pickham et al.'s study and $28 \%$ in the study of Tisdale et al., $52 \%$ of the patients in the study of Kozik et al found the basal QTc rates prolonged ${ }^{22}$, 23,24 . The reason for this different result was the use of drugs that prolong QT in intensive care unit in the studies of Pickham, Tisdale, and Kozik, while the patients in our study were not exposed to medications that prolong the QT interval.

In our study, no significant decrease in $\mathrm{SpO}_{2}$ values was observed in any of the patients due to $100 \% \mathrm{O}_{2}$ administration for 1 minute before the endotracheal aspiration. Although intensive care units generally consist of patients with limited cardiac reserve; since no desaturation was observed due to preoxygenation before aspiration, no significant tachycardia and hypertension secondary to hypoxemia were observed in our patients. In our study, no significant change was observed in hemodynamic parameters of our patients during and after aspiration. We also believe that the average age of the patients in our study is not high and this situation also has a role in maintaining hemodynamic parameters.

In order to provide adequate oxygenation in intensive care patients, mechanical ventilation with endotracheal intubation is frequently applied. In order to provide optimum benefit from mechanical ventilation treatment, sedative agents are used to prevent patient incompatibility with ventilator. Therefore, sedative agents should have a positive effect on oxygenation in intensive care patients connected to a mechanical ventilator. Although we did not use a sedative agent in our study, $\mathrm{SpO}_{2}$ monitoring which is an indicator of oxygenation was used. There was no significant decrease in $\mathrm{SpO}_{2}$ value of the patients during the aspiration procedure. No significant relationship was found between $\mathrm{SpO}_{2}$ and QT-QTc values.

It has been reported by many investigators that stress caused by laryngoscopy and tracheal intubation resulted in prolongation of QT interval ${ }^{25}$. In addition, prolongation of the QT interval has been shown to be related to the amount of catecholamines that are released during adrenergic stimulation caused by laryngoscopy and surgery ${ }^{26}$. As in many studies with prolonged Qt interval due to different etiological factors, a significant prolongation of the QT interval was detected during aspiration in this study and this was confirmed by QTc. There was no fatal 
ventricular arrhythmia in patients with prolonged QTc values. Considering that every medication and every interventional procedure to be performed in the intensive care unit may affect the QT interval, we believe that QT prolongation must be considered with life-threatening lethal arrhythmias in the follow-up of patients.

Considering the prolonging effect of aspiration on QT interval in ECG; the aspiration process should be completed as soon as possible, secretions should be softened for shortening the aspiration time, if open aspiration is performed, sterile gloves and disposable aspiration catheter should be used in terms of infection risk, if possible, aspirators should be specific to the patient. If a closed aspiration catheter system is used, it must be changed in case of perforations or tear and wear in the catheter preserver. The choice of which system will be used affects the quality of health care services. In our study, we preferred closed circuit aspiration catheters. If the patient is connected to the mechanical ventilator device in the intensive care unit, by means of closed-circuit catheters, aspiration process can be performed easily without too much interrupting the ventilation process and without disconnecting the patient from the device. In this way, there is not much change in the oxygen saturation and hemodynamic parameters of the patient. Therefore, complications such as hypoxemia, hemodynamic instability and cardiac arrhythmias due to aspiration do not develop. Of the patients, 15 patients had arrhythmia during aspiration and 9 of them had cardiogenic diagnoses.

None of our patients had fatal severe arrhythmia and cardiac complication. QT interval prolongation should always be checked by calculating corrected QT interval, and there is a need to be more careful in patients with coronary heart disease and congenital prolonged QT interval in terms of fatal ventricular arrhythmias. It's obvious that there is a need for more studies about this issue.

\section{REFERENCES}

1. Kaplan JA, Thys DM. Electrocardiography. In: Miller RD Anesthesia Vol.1 3th ed. Churchill Livingstone 1990: 1101-1127.

2. Davies JM. Complication of general anaesthesia. In: Nimmo WS, Smith G. Anesthesia Vol. 1 Blackwell Scientific Publications 1989: 502-521.

3. Booker PD, Whyte SD, Ladusans EJ. Long
QT syndrome and anaesthesia. Br J Anaesth 2003; 90: 349-66.

4. Al-Refai A, Gunka V, Douglas J. Spinal anesthesia for Cesarean section in a parturient with long QT syndrome. Can J Anaesth. 2004; 51: 993-6.

5. Arildsen H, May $\mathrm{O}$, Christian EH, et al. Increased QT dispersion in patients with insulin dependent diabetes mellitus. International Journal of Cardiology 1999; 71: $235-42$.

6. Andreoli T, Bennett CJ, Carpenter CJ, Plum F, Smith LH. Cecil Essentials of Medicine,

Elektrokardiografi,1993: 21-23.

7. Guglielminotti, J, Alzieu, M, Maury E, Guidet B, Offenstadt $\mathrm{G}$. Bedside detection of retained tracheobronchial secretions in patients receiving mechanical ventilation. Clinical Investigations in Critical Care. 2000; 118: 1095-1099.

8. Giakoumidakis K, Kostaki Z, Patelarou E, Baltopoulos G, Brokalaki H. Oxygen Saturation and Secretion Weight After Endotracheal Suctioning. British Journal of Nursing, 2011; 20(21): 1344-135.

9. American association for respiratory care: AARC clinical practice guidelines. Endotracheal suctioning of mechanically ventilated patients with artificial airways 2010. Respir Care, 2010; 55(6): 758-764.

10. Pedersen MC, Rosandalh-Neilsen M, Hjerment J, Egerod I. Endotracheal suctioning of the adult intubated patient; What is the evidence? Intensive and Critical Care Nursing, 2009; 25(1): 21- 30.

11. Majeed S, Majee A, Shambhavi M. Effectiveness of planned teaching programme on knowledge and practice ofendotracheal suctioning among staff nurses in selected hospitals of mangalore. Asian J. Nursing Edu. and Research, 2013; 3(4): 243-247.

12. Beuret P, Roux C, Constan A, Mercat A, Brochard L. Discrepancy between guidelines and practice of tracheal suctioning in mechanically ventilated patients; A french multicenter observational study. İntevsive care med, 2013; 39: 1335-1336.

13. Moss AJ, Long QT. Syndrome. JAMA. 2003; 289: 2041. 
14. Drici MD, Cle'ment N. Is gender a risk factor for adverse drug reactions? The example of drug-induced long QT syndrome. Drug Saf. 2001; 24: 575.

15. Drew BJ, Ackerman MJ, Funk M, et al. Prevention of torsade de pointes in hospital settings: a scientific statement from the American Heart Association and the American College of Cardiology Foundation. Circulation. 2010; 121: 1047.

16. Kopp BJ, Erstad BL, Allen ME, et al. Medication errors and adverse drug events in an intensive care unit: direct observation approach for detection. Crit Care Med. 2006; 34: 415-25.

17. Krishnan V, Murray P. Pharmacologic issues in the critically ill. Clin Chest Med. 2003; 24: 671-88.

18. Avcı O, Gürsoy S, Kaygusuz K, Özdemir Kol İ, Düger C, İsbir C. The effects of sedative agents used in intensive care unit on QT interval. Cumhuriyet Medical Journal 2017; 39: 417-429

19. Kane-Gill SL, Weber RJ. Principles and practices of medication safety in the ICU. Crit Care Clin. 2006; 22: 273-90.

20. Goldstein DS. The electrocardiogram in stroke: relationship to pathophysiological type and comparison with prior tracings. Stroke. 1979; 10: 253.
21. Cooke RA, Chambers JB, Singh R, et al. QT interval in anorexia nervosa. Br Heart J. 1994; 72: 69.

22. Pickham D, Helfenbein E, Shinn JA, Chan G, Funk M, Weinacker A, et al. High prevalence of corrected QT interval prolongation in acutely ill patients is associated with mortality: Results of the QT in Practice (QTIP) Study. Crit Care Med 2012; 40: 394-9.

23. Tisdale JE, Wroblewski HA, Overholser BR, Kingery JR, Trujillo TN, Kovacs RJ. Prevalence of QT interval prolongation in patients admitted to cardiac care units and frequency of subsequent administration of QT interval-prolonging drugs: A prospective, observational study in a large urban academic medical center in the US. Drug Saf 2012; 35: 459-70.

24. Kozik TM, Wung SF. Acquired long QT syndrome: Frequency, onset, and risk factors in intensive care patients. Crit Care Nurse 2012; 32: 32-41.

25. Owczuk R, Wujtewicz MA, Sawicka A, Piankowski A, Polak-Krzeminska A. The effect of intravenous lidocaine on QT changes during tracheal intubation. Anaesthesia, 2008;63:924-931.

26. Andreoli T, Bennett CJ, Carpenter CJ, Plum F, Smith LH. Cecil Essentials of Medicine, Elektrokardiografi,1993: 21-23. 